\title{
Improving Professional Speech Culture of Teachers of Russian Language and Literature
}

\author{
Anna A. Larionova ${ }^{1}$, Tatyana A. Korneyeva ${ }^{2}$, Zulfiya F. Yusupova ${ }^{3}$, Landysh G. Latfullina ${ }^{4}$ \\ ${ }^{1,2,3}$ Kazan Federal University, Leo Tolstoy Institute of Philology and Intercultural Communication \\ ${ }^{4}$ Moscow State Pedagogical University, Institute of Philology \\ Email:annaribka86@mail.ru
}

Received: 21st October 2017 Accepted: 16th November 2017, Published: 31st December 2017

\begin{abstract}
The article proposed is devoted to the study of typical mistakes in speech of the students-philologists passing the pedagogical practice in the Russian language and the development of practical recommendations on forming the professional speech culture of future teachersphilologists in the context of recommendations of the teacher's professional standard and on the basis of modern scientific research in pedagogical rhetoric, pedagogical speech, orthology and communication theory. The paper presents the sample analysis results of the statements of students-trainees and teachers of the Russian language. The study purpose is to develop practical recommendations for improving the professional speech culture of teachers-philologists. The leading research methods included such as analysis, observation, comparison, generalization. We classified and described intonation, speech, grammatical, logical, ethical, communicative and other errors in the speech of students. Our conclusions: more attention should be paid to the study of some features of speech behavior and speech impact of leading teachers with subsequent analysis, to the inclusion of the intonation drawing of the lesson (for beginner teachers) in the lesson abstract (technological map of a lesson), to the fixing of individual difficulties with subsequent correction in training the teachers-philologists. The materials of this article are of practical value for improving the work on forming the subject and professional competencies of the teacher-philologist in the conditions of introducing the professional standard of a teacher.
\end{abstract}

Keywords: Education, Russian Language, Professional Standard of a Teacher, Pedagogical Speech Studies, Speech Culture of the Teacher-Philologist, Speech Errors.

\section{Introduction}

The relevance of this topic is conditioned by the new requirements for the preparation of the Russian language teacher, set out in the draft concept and content of the professional standard of a teacher published on February 15, 2013 by the Ministry of Education and Science of the Russian Federation, the requirements of the FSES (Federal State Education Standards) for the content and organization of educational process in the modern school, the persistent attention of a wide scientific and pedagogical community to the relevant issues of orthology and the problems of teaching the Russian language and speech culture in the educational institutions of various types, as well as the existing contradictions between school and scientific grammar. The research issue is in revealing typical mistakes in speech of the students-philologists passing the pedagogical practice in the Russian language and the development of practical recommendations on forming the professional speech culture of future teachersphilologists in the context of recommendations of the teacher's professional standard and on the basis of modern scientific research in pedagogical rhetoric, pedagogical speech, orthology and communication theory.

The study purpose is to develop practical recommendations on improving the professional speech culture of teachers-philologists in the conditions of continuous education and in the context of recommendations of the professional standard of a teacher, as well as recommendations on forming the professional competencies related to increasing the motivation to learn and developing the language culture of students-philologists. The theoretical basis of the study included the works of T.A. Ladyzhenskaya [8], L.A. Vvedenskaya [4], L.K. Graudina [5], E.N. Shyryaeva [5], L.A. Mardieva [13, 18], T.Yu. Shchuklina [13, 18], Z.F. Yusupova [6, 14], T.A. Korneeva [15, 16], the works of I.A. Baudouin de Courtenay [3], V.A. Bogoroditsky [2], G.A. Nikolaev [9], E.A. Balalykina [1], as well as their students and followers.

\section{Material and Methods}

Research methods: method of linguistic description, word-formation and grammatical analysis, linguistic forecasting, theoretical analysis of literature, generalization of best practices, practice-oriented design, empirical methods: observation, ascertaining experiment, conversation. The study material included an error cardfile containing over 1,000 statement samples of the students, a speech record of the Russian language teachers - participants in the All-Russian contest of master classes of teachers "Tugan tel", conducted by the Ministry of Education and Science of the Republic of Tatarstan in 2015-2017. We took into account the results 
of oral and written round of the All-Russian Olympiad of schoolchildren and students in the official languages of the republics of the Russian Federation under the auspices of the Russian language (Kazan, Moscow, 2016) among students of humanitarian direction, the predominant majority of whom were from the Russian pedagogical institutions and universities.

\section{Results}

Based on the research conducted, we determined the main groups of typical speech errors of the studentsphilologists: intonation, speech, grammatical, logical, ethical, communicative, flaws in the use of non-verbal communication means. In the transition conditions to the FSES of new generation, the professional standard of the Russian language teacher is represented by a normative document that primarily determines the subject competence of the Russian language teacher. It is specified on the first place in the standard that "the Russian language teacher should:

- Observe the contextual language norm. Do not allow massive errors in the oral and written speech: "parasitic words", chancellarisms, erroneous accents and forms in the words used in working with students.

- $\quad$ He should carry out an autocorrection. In case of doubt, somebody's remark, a collision with the alternative, he should turn to the intelligent and orphoepic sources of the Internet.

- He should know and use the standard allRussian pronunciation and vocabulary, demonstrating their differences from the local language environment. $<\ldots>$

- $\quad$ He should conduct continuous work with the families of students and the local community to form the speech culture, recording differences in local and national language norms, the culture of short text messages, the use of telecommunications and the work with the Internet sources.

- $\quad$ He should give an ethical and aesthetical assessment of language manifestations in everyday life: Internet language, the language of subcultures, the language of mass media, profanity". [14: 38]

The professional standard requirements "oblige" the Russian language teachers to have a high (elite) type of speech culture and conduct extensive educational work on the upbringing and improvement of the speech culture of the population.

The main groups of typical speech errors of studentsphilologists include the following.

1) The intonational mistakes associated with the setting of incorrect logical stress irrelevant in terms of semantics pauses or, conversely, the absence of necessary functional pauses of the lesson, intonational monoton, speech inexpressiveness, inability to vary intonation depending on the communicative task. This type of errors manifests itself most often when working with a coherent text - the main didactic unit in the Russian language lessons. Elimination of such errors is contributed by the work with audio recordings of artistic reading of works of Russian classics, phonocrestomatia with audio recordings of literary works performed by famous stage masters. As a rule, phonocrestomatia is accompanied by assignments that "offer students to analyze the performance interpretation of the text, expressive possibilities of oral performance, role of timbre, height of the voice, changes in rhythm and intonation in conveying the artistic originality of the literary work" [6: 38]. Another type of intonational mistakes of young teachers of the Russian language is connected with the methods and means of organizing the educational activity of schoolchildren. There are syntactical, non-syntactical, psychological pauses (pauses of remembering, silence, tension), "eloquent pauses", pauses of disciplinary nature, etc. in the pedagogical speech. [10: 142] The students' mistakes arise from the non-possession of "rhetorical" pauses: pause for attracting students' attention, pause for allocating the important information, pause for reflecting and assimilating difficult material by the schoolchildren, pause for "rest", pause for demonstrating confidence, pause for separating speech into parts, pause-substitution for extra words (parasitic words), pause for ending the lesson and some other kinds of pauses. The formation of intonational literacy of students studying in the direction of "pedagogical education" requires more attention, because intonation is one of the most important educational tools of the Russian language teacher's influence on the children and adult audience.

2) Speech errors that determine the professional conformity/inconsistency of the Russian language teacher. The following errors are noted among the most frequent in written and spoken language.

The word usage in an uncharacteristic meaning: ...the peoples were not assimilated by a larger culture; language is not an object, but an intermediary, due to which and through which we express ourselves and things; language is the main tool of any people; make an incredible contribution; the language owner. Unsuccessful use of pronouns: I want to give a few arguments in my confirmation.

The use of words of a different style: they seem to speak through the nose. Non-distinction of the shades of meaning that are introduced into the word by a suffix: the desire for order and balance. Destruction of the figurative meaning of phraseology in an unsuccessfully organized context: this is really what tickles my heart; where many nationalities live the shoulder in the shoulder. Violation of lexical compatibility: Homeland this is where you grew up, where you made the first steps...; give due honor to your ancestors; supportive attitude towards relatives; tolerant attitude to other people's worldview values; only then will harm, pride and love for one's country reign. Word-making: linguistograph; linguoculture of languages, etc.

3) Grammar errors are the most difficult material for correction. Typical grammatical errors include the 
following: erroneous formation of the forms of noun, adjective, numerative, pronoun, verb (personal forms of verbs, real and passive participles, gerunds): it is necessary to think more attentively in the author's words...; this aphorism sounds even more like a precept; being a representative of one of the nationalities of Russia; language is one of the most important values that a person can have; language preservation, concern for its dissemination and enrichment is the main task of each of us; Violation of harmonization standards: language is a kind of lace. Errors in constructing a sentence with homogeneous terms: these qualities should be owed by such rich, mighty languages as Russian. Errors in constructing a sentence with homogeneous terms: let's protect, honor and speak in the official languages of Russia. Errors in constructing a complex sentence: to convey to the interlocutor how beautiful the world is.

Breach of sentence boundaries: I am very glad that I was born in a country like Russia. In which there is a place for every nationality and every language. Violation of the temporal correlation of verbal forms: I do not understand a man who has not known and does not understand his native language...

4) The logical mistakes of future teachers are related to the violation of the rules for planning the Russian language lesson, the definition of the sequence of tasks and exercises. As a rule, the structure of the Russian language lesson presupposes a movement "from simple to complex", from the language units of the lowest level to the language units of the highest level: from the words through the phrase and sentence to the connected text. Possible deviations from this rule are always due to the nature of the language material being studied.

5) Ethical errors in the speech of students studying in the direction of "pedagogical education" are less common than other types of errors and, as a rule, are related to the inability to organize the training activity of schoolchildren, to regulate the relations between the students. Hence there is the ill-will, the manifestation of verbal aggression, a negative, incorrect assessment of the students' actions. Young teachers also use the individual slang words and speech tokens in the speech.

6) The communicative mistakes of students-trainees are caused, on the one hand, by the violation of accepted communication standards: inability to listen to the student's response, the habit of interrupting, the failure to follow the methodology of setting the academic question, the misunderstanding of the students' interests, etc., on the other hand - the inability to organize a pair and group work, difficulties in setting up a learning task.

7) Errors in using the nonverbal communication tools. This is excessive gesticulation, sometimes inappropriate tactile movements, including touching, stroking students on the head, patting, not quite appropriate to the academic (school) environment, appearance, postures, walking distracting students during the lesson. In general, there is the unformed culture of pedagogical communication.

\section{Discussion}

As can be seen from the analysis, a typical mistake of trainee students in the organization of a problem dialogue is verbal, grammatical and methodological inconsistency of questions and attitudes to the communicative and educational tasks. This is evident from the example of the following fragment of the Russian language lesson (the speech of a trainee teacher is given): What exercise was given you as a home task? / Maybe, Zarina? / Come on, read it to us. / Come on, Katya, go to the blackboard. / Let's write down the sentence. / Please, write everything. I Please, find where we have gerundance there? (February, 2017) As a rule, the beginning teachers, without waiting for the answers of students, answer their own questions or formulate questions in such a way that the answer is unambiguous: yes or no. In this case, it is difficult to obtain a full, detailed answer of the students.

\section{Conclusions}

In connection with the above, work on improving the methodological skills of students, eliminating verbal and methodological mistakes in the formulation of motivational tasks, updating knowledge, skills, creating a problem situation, organizing problem dialogue, pair and group work, independent educational activity, etc., becomes especially important $[7,11,12,17,18]$.

Conclusions and recommendations. The speech culture of the teacher-philologist is a reflection of his general culture, the breadth of the linguistic outlook and requires constant improvement in the face of ever-changing reality and the new psychological and pedagogical requirements for the educational process. In this regard, more attention should be paid to the study of some features of speech behavior and speech impact of leading teachers with subsequent analysis, to the inclusion of the intonation drawing of the lesson (for beginner teachers) in the lesson abstract (technological map of a lesson), to the fixing of individual difficulties with subsequent correction, to the analysis of own speech behavior with the use of modern audio and video devices, to the analysis of the newest literature on the theory of communication and pedagogical speech, to the formation of professional competence, enhancing motivation for self-learning and self-development in training the teachers-philologists. The requirements for a high level of professional speech culture of a teacher-philologist are not only the most important recommendation of the professional standard of a teacher, but also a requirement for a modern teaching and educational process in the school and university.

\section{Acknowledgements}

The researches performed according to the Russian Government Program of Competitive Growth of Kazan Federal University. 


\section{References}

[1] Balalykina E.A. (2012) Metamorphosis of the Russian Word. Study Guide. M.: FLINTA: Nauka, 264 p. [2] Bogoroditsky V.A. (2005) General Course of Russian Grammar: from the University Readings. M.: KomKniga, $576 \mathrm{p}$.

[3] Baudouin de Courtenay I.A. (1963) Selected Works on General Linguistics. V. II. M.: Publishing house of the USSR Academy of Sciences, $391 \mathrm{p}$.

[4] Vvedenskaya L.A. (2008) Rhetorics and Speech Culture: Study Guide for the Students of the Higher Educational Institutions / L.A. Vvedenskaya, L.G. Pavlova. Rostov-on-Don: Feniks, 537 p.

[5] Graudina L.K. (2004) Grammatical Correctness of Russian Speech: Stylistic Dictionary of Options / L.K. Graudina, V.A. Itskovich, L.P. Katlinskaya; Russian Academy of Sciences, Institute of Russian Language named after V.V. Vinogradov. M.: Astrel, 555 p.

[6] Kryukova, N.I., Zakharova, A.N., Dulina, G.S., Yusupova, Z.F., Belonovskaya, I.D., Bogdanova, J.N. (2017) Didactic features of pedagogical interaction as the basis of university education // Man In India, Vol. 97. No. 3.pp. $29-41$.

[7] Brief Russian Grammar (1989) / Edited by Shvedova N.Yu., Lopatin V.V. M.: Nauka, 639 p.

[8] Ladyzhenskaya T.A. (1998) Pedagogical Speech. Reference Dictionary. 2nd edition, revised and extended / Edited by T.A. Ladyzhenskaya and A.K. Mikhalskaya; M.: FLINTA: Nauka, 312 p.

[9] Nikolaev G.A. (2011) Russian and Slavic Word Formation. Kazan: Kazan University, 220 p.

[10] Professional Standard of a Teacher // http://минобрнауки.рф/документы/3071/файл/1734/12. 02.15-Профстандарт_педагога_(проект).pdf (Access date 18.06.2017)

[11] Rakhimova D.I., Fedorova N.I. (2016) Semantic, grammar and functional features of personal pronouns in Russian and Tatar languages / Rakhimova D.I. Fedorova N.I.// 3rd International Multidisciplinary Scientific Conference on Social Sciences @ Arts SGEM 2016 // Book 1. Conference on Psychology, Psychiatry, Sociology, Healthcare, Education. Conference proceedings. Volume III. Education and Educational Research (24-30 august, 2016). Albena. Bulgaria. PP. 897-902.

[12] Nurullina G.M. (2016) The use of dictionaries in teaching Russian language to bilingual students // Modern Journal of Language Teaching Methods: Special Issue (December 2016). PP. 92-96.

[13] Alyokhina T.A., Shchuklina T. Yu., Mardieva L.A. (2016) Teaching Russian composites: normative and derivative aspects (on the material of compound adjectives in the Russian language) // Modern Journal of Language Teaching Methods. Special Issue. PP. 207-211. [14] Fattakhova N. N. (2016) A New Model of Pedagogical Magistracy in the Direction of Linguistic Education at Kazan Federal University / Fattakhova N.N., Yusupova Z.F., Fedorova N.I.// IFTE 2016 - 2nd 2318 international forum on teacher education. 2016. Vol.12, Is.PP.26-29

[15] Korneyeva T.A. On the Problem of Learning the Difficult Questions of Linguistics at Russian Lessons // The European Proceedings of Social \& Behavioral Sciences EpSBS. Volume XII. Pages 313-321.

[16] Shaikhutdinova R.I., Korneyeva T.A. (2016) The methods for studying zero affixation in school // Modern Journal of Language Teaching Methods, PP. 76-78.

[17] Husnutdinov D.H., Shakurova M.M. (2016) Practical aspect of comparative research on the material of the Russian and Tatar languages: XIX-XXI centuries // Journal of Language and Literature. 2016. Vol.7, Is.2. PP.191-194.

[18] Shchuklina T., Mardieva L., Alyokhina T. (2016) Teaching Russian language: the role of word formation // The European Proceedings of Social and Behavioral Sciences (EpSBS). Volume XII. PP. 190-196. 